AperTO - Archivio Istituzionale Open Access dell'Università di Torino

\title{
Why Do Firms (Dis)Like Part-Time Contracts?
}

\section{This is a pre print version of the following article:}

Original Citation:

Availability:

This version is available http://hdl.handle.net/2318/1740618

since 2023-01-26T10:53:27Z

Published version:

DOI:10.1016/j.labeco.2020.101864

Terms of use:

Open Access

Anyone can freely access the full text of works made available as "Open Access". Works made available under a Creative Commons license can be used according to the terms and conditions of said license. Use of all other works requires consent of the right holder (author or publisher) if not exempted from copyright protection by the applicable law. 


\title{
Why Do Firms (Dis)Like Part-Time Contracts?
}

\author{
Francesco Devicienti $^{\mathrm{a}, \mathrm{b}, *}$, Elena Grinzac ${ }^{\mathrm{c}}$, Davide Vannoni ${ }^{\mathrm{a}} \mathrm{b}$ \\ ${ }^{a}$ Department of Economics, Mathematics, and Statistics, University of Turin, \\ Corso Unione Sovietica 218 Bis - 10134, Turin (Italy) \\ ${ }^{b}$ Collegio Carlo Alberto, Piazza Vincenzo Arbarello 8 - 10122, Turin (Italy) \\ ${ }^{c}$ Department of Management and Production Engineering, Politecnico di Torino \\ Corso Duca degli Abruzzi 24 - 10129 Turin (Italy)
}

\begin{abstract}
This paper investigates the costs for firms of employing women full-time versus part-time in terms of differential hourly wages. To this end, we use administrative matched employeremployee data on the universe of female workers in Italy over 33 years and rely on regression models that control for worker, firm, and job match fixed effects, in addition to several worker-, job-, and firm-level time-varying factors. We find that, when a worker switches from a full-time to a part-time contract within the same firm, she benefits from an increase in the hourly wage. Over the last three decades, these wage premiums have significantly reduced, remaining positive and significant up to 2015. We also find that the part-time premium is pervasive and stable across many different labor market segments and independent of workers' intrinsic productivity levels. These and other findings appear to be compatible with developments in wage bargaining institutions, whereby more generous conditions can be accorded to part-timers. Coupled with the detrimental effect of part-time work on firm productivity documented by Devicienti et al. (2018), our results contribute to explain why firms are often unwilling to concede part-time positions to employees asking for them.
\end{abstract}

Keywords: Part-time/full-time wage differentials, wage bargaining institutions, multiple fixed effects regressions, administrative matched employer-employee longitudinal data.

JEL: J31, J22, J53.

${ }^{*}$ We kindly acknowledge funding support and data access provided by the VisitINPS program. Francesco Devicienti and Davide Vannoni also gratefully acknowledge the funding support of MIUR - Ministry of Education, University, and Research (Financing Fund for Departments of Excellence) and of the PROWEDEC (Productivity, Welfare, and Decentralized Bargaining) project, financed by the Compagnia di San Paolo. We thank Edoardo Di Porto and Paolo Naticchioni for their general help and suggestions with INPS data usage. We also thank Michelangelo Filippi and Roberto Quaranta for sharing with us their knowledge on the INPS variables related to part-time work, and Ainoa Aparicio Fenoll, François Rycx, and Claudia Villosio for their helpful comments. We gratefully acknowledge insightful comments and suggestions from the Editor and two anonymous referees.

Corresponding author: francesco.devicienti@unito.it. 


\section{Introduction}

Many experts stress that part-time work is a valuable instrument of work-life balance since it allows people to better conciliate work with private life needs (Eurofound and ILO, 2019; Eurostat, 2009; OECD, 2017). However, both anecdotal and available statistical evidence suggests that workers who wish to switch to a part-time work schedule often encounter the resistance, if not the outright opposition, from their employer. A quick search on the Internet confirms this: there are plenty of online forums where workers complain that employers do not allow them to work a reduced number of hours. It is not unusual that workers, particularly females, are forced to quit their jobs following the denied request to switch to a part-time work arrangement. Accordingly, Gasparini et al. (2012) report that only about 30\% of fulltime employees in the EU-15 feel that their employer would view their request to reduce working hours favorably.

There might be several reasons why firms are typically not willing to accomplish the requests of their workers to switch to a part-time contract. Communication and start-up costs associated with part-time work as well as difficulties in optimally staffing part-time employees might impose efficiency losses on the organizational structure of firms. In a recent study, we find that part-time work is indeed linked to significantly lower firm productivity and that this result holds for different categories of firms and after accounting for a large number of worker- and firm-level characteristics (Devicienti et al., 2018). If firms can compensate for this productivity gap associated with part-time work by offering lower wages to parttime contracts, they should be indifferent between employing workers full-time or part-time, and thus fulfilling workers' requests to switch to part-time arrangements. However, this is typically unfeasible in most industrialized economies, where the law dictates that part-time contracts must enjoy the same monetary (and non-monetary) benefits of comparable full-time contracts. In some countries, such as Italy, the law even allows for more favorable treatment to part-time contracts. The emergence of a zero or positive part-time/full-time wage differential, coupled with the lower productivity associated with part-time arrangements, would then help to understand the firms' reluctance to accommodate workers' requests to switch to part-time schedules. In this paper, we aim at understanding whether this happens. In other words, we tackle the analysis from the firms' viewpoint and aim at estimating whether part-time schedules have a different cost, in terms of hourly wages, compared to full-time arrangements.

To do so, we use a vast data set, which covers the universe of private-sector employees in Italy over more than 30 years. This data set is based on administrative data from the Italian Social Security System (INPS) and links each employee to the firm she works in, thereby allowing to exploit rich longitudinal worker-, firm-, and job-level information. This 
information at multiple levels is crucial to assess the presence of any wage differentials associated with part-time arrangements since a multitude of factors at these various levels can simultaneously determine wages and part-time work status. We concentrate on the impact of a change in the working time arrangements of the same worker within the same firm. In synthesis, this allows removing any confounding effects due to unobserved fixed worker, firm, and job-match heterogeneity. At the same time, we control for an ample set of time-varying observable factors, which might also confound the effect. Particular attention is devoted to controlling for the employee's working history, with specific reference to accumulated experience in the labor market, in part-time and full-time work. We also pay attention to possible contemporaneous endogeneity stemming from maternity and employer undergoing periods of economic crisis, which are likely to simultaneously influence a change in the working schedule and wages.

In this study, we focus on females. This is for several reasons. First, females constitute the vast majority of part-time workers. Second, we concentrate on females because they represent the most relevant segment for the aims and policy implications of this paper. Females are those that typically ask for (temporary) transitions into part-time work, often to conciliate work with family commitments. A denied request to switch to a part-time arrangement may entail withdrawal from work, with well-known long-lasting consequences in terms of earnings and the possibility to successfully re-enter the labor market. Third, male part-time work is a very heterogeneous phenomenon and, differently from what happens for women, mostly involuntary (i.e., most part-time men work part-time while willing a fulltime position). Fourth, we concentrate on females for comparative purposes. As we will discuss below, most studies examining part-time/full-time wage differentials have focused on females.

Several papers have analyzed part-time/full-time wage differentials, but most of them have investigated the issue from the workers' viewpoint. These studies were mainly interested in assessing the determinants of part-time/full-time wage differentials, and how the part-time status influences future earnings and career trajectories of workers. Particular attention has been devoted to gender issues, either by concentrating the analysis on women or by juxtaposing part-time earnings differentials and gender wage gaps (Manning and Petrongolo, 2009; Matteazzi et al., 2018; Mumford and Smith, 2009; Pacelli et al., 2013); to the impact of switching to a part-time contract on future earnings and career prospects of workers (Connolly and Gregory, 2009; Fernández-Kranz and Rodríguez-Planas, 2011; Paul, 2016); and to the presence of a possible heterogeneity of part-time wage differentials along the wage distribution (Gallego Granados, 2019; Nightingale, 2019; Simon et al., 2017).

This paper contributes to the existing part-time literature in several ways. It is one of 
the few studies that explore the wage effect of switching to a part-time contract while at the same employer. Moreover, the use of administrative data on the universe of workers and firms over more than three decades allows us to explore the long-run dynamics of the part-time/full-time wage differential for the universe of Italian workers, and to run separate analyses on many different categories of workers and firms, based on, for instance, age, migration status, parenthood, job duration, occupation, and the firm's size, industry, and location. The dimension of our data entails that, for each of these analyses, we can remove confounding factors related to worker, firm, and match-specific unobserved heterogeneity. Furthermore, in order to explore the mechanisms at work, we investigate if effects vary between short and long part-time work (as in Paul, 2016) and between switches from fulltime to part-time work and switches from part-time to full-time arrangements (as in Booth and Wood, 2008, and Day and Rodgers, 2015). We also explore the relevance of mechanisms related to workers' commuting and differential rent-sharing by part-time status within the firm.

Using longitudinal matched employer-employee data to estimate part-time/full-time wage differentials in Spain, Fernández-Kranz and Rodríguez-Planas (2011) are, to the best of our knowledge, the only scholars controlling for both individual- and firm-level unobserved fixed heterogeneity, as we do in this paper. ${ }^{1}$ They report significant part-time wage penalties for female workers, which remain after controlling for individual and firm fixed heterogeneity, and are particularly pronounced for temporary workers. Our estimates instead point to the existence of pervasive wage premiums associated with part-time work schedules, which are transversal to many different segments of the labor market. These and additional results are compatible with part-time premiums stemming from the relatively higher protection accorded to (female) part-time workers by unions and sectoral collective agreements.

The rest of the paper is structured as follows. Section 2 briefly discusses the mechanisms that can lead to a wage differential between part-time and full-time work schedules. Section 3 reviews the existing empirical literature on the part-time/full-time wage differential along two main dimensions: estimation methods and cross-country evidence. Section 4 outlines our empirical model, the type of effect that we identify, and its relation with previous empirical works. Section 5 describes the data, Section 6 shows and discusses our results, and, finally, Section 7 draws the implications of our findings and concludes.

\footnotetext{
${ }^{1}$ However, while we have data on the universe of Italian employees over 33 years, they use a $4 \%$ nonstratified random sample of the population registered with the Spanish Social Security Administration in 2006, which amounts to a sample of about 76,000 individuals observed over the years 1996-2006.
} 


\section{Conceptual framework}

There are several theoretical explanations as to why firms may pay full-timers different hourly wages than part-timers.

A first mechanism relates to productivity differentials between the above two categories of workers, which - absent wage rigidity - should be reflected in wage differentials. Part-timers may be less productive than full-timers due to daily start-up costs, whereby the individual productivity of labor is lower during the first hours of work and picks up only slowly during the day (Barzel, 1973). Also, part-time work may impose firm-wide communication and coordination costs that can be of detriment to the firm's overall efficiency (Owen, 1978). However, part-timers may also be more productive compared to full-timers if stress reductions from working fewer hours offset the above-mentioned adverse effects (Moffitt, 1984; Tummers and Woittiez, 1991). Overall, the existing evidence for Italy points to significant productivity losses associated with part-time work arrangements (Devicienti et al., 2018).

A second set of mechanisms relates to the notion of compensating wage differentials. Individuals requesting shifts to part-time arrangements (e.g., due to childcare duties) may be willing to accept lower hourly wages in exchange for the possibility of working reduced hours. If firms find it costly to arrange part-time schedules, part-time wage penalties arise in equilibrium. Apart from lower productivity possibly associated with part-time work, firms typically face fixed labor costs (e.g., hiring and training costs). These costs increase proportionally with the number of employees rather than with hours worked, thus making part-time work schedules relatively more expensive (Montgomery, 1988; Oi, 1962).

Alternatively, workers may require an increase in hourly wages to compensate for the reduction in total labor earnings (and possibly consumption) associated with the reduction in hours of work. Compensation for part-time schedules may also be required when workers have to bear commuting costs, both in terms of time spent to reach the job location or because they have to pay a fixed cost, such as a seasonal train/bus or parking ticket. ${ }^{2}$ Compensation for part-time arrangements may also happen if part-timers are less likely than full-timers to obtain non-wage benefits or other amenities at the workplace (as argued by Paul, 2016, and Bardasi and Gornick, 2008). As we aim at understanding a firm's resistance to conceding part-time positions to their employees, compensating wage effects following switches from a full-time to a part-time contract occurring within the same firm are of particular interest.

A third reason for differential hourly wages by part-time/full-time status is that part-

\footnotetext{
${ }^{2}$ Mulalic et al. (2014) have analyzed the effect of commuting distance on workers' wages. Using the event of firm relocations in Denmark as a quasi-natural experiment, they found that employers accord a wage increase to their workers as compensation for higher commuting costs.
} 
timers may suffer from (statistical) discrimination, despite this is typically prohibited by law. In Italy, as well as many other advanced industrialized countries, the legislation concerning part-time work imposes strict rules against the discrimination of part-timers. In particular, it dictates that part-time workers must enjoy the same monetary (e.g., wage, monetary bonuses) and non-monetary (e.g., paid sick leave, parental leave) treatment of comparable full-time workers according to a pro rata temporis principle.

Finally, collective bargaining may affect the ability of wages to reflect workers' productivity. In many countries, including Italy, the law leaves sectoral collective agreements free to dictate more favorable treatments for part-time workers. Individual- and firm-level bargaining are often too weak to undo (and may even strengthen) the dispositions set by unions at the industry level. On their part, unions might disproportionately defend the weaker segments of the labor force, typically including (female) part-timers. If so, de-unionization and wage decentralization - recently observed in many EU countries, and often advocated by policy commentators - may associate with a deterioration of any wage privilege previously associated with part-timers.

\section{Previous empirical literature}

The existing evidence on the presence of part-time/full-time wage differentials is mixed and dependent on the type of data and estimation methods utilized. Many studies have focused on cross-sectional surveys of workers, and have typically found wage penalties associated with part-time work, which often remain after controlling for a series of individual-, firm-, and job-level characteristics (Bardasi and Gornick, 2008; Elsayed et al., 2017; Hardoy and Schøne, 2006; Jepsen et al., 2005; Manning and Petrongolo, 2009; Matteazzi et al., 2014; Mumford and Smith, 2009). A typical result from these studies is that the part-time pay penalty reduces significantly after taking into account occupational categories, pointing to a crucial role of occupational segregation in explaining observed part-time wage penalties. Other researchers have instead used individual longitudinal survey data (Booth and Wood, 2008; Connolly and Gregory, 2009; Day and Rodgers, 2015; Hirsh, 2005; Paul, 2016), and found that part-time penalties significantly reduce, often disappear, and sometimes even transform into part-time premiums once worker fixed effects are included in the regressions. Therefore, unobserved individual heterogeneity (e.g., differences in abilities and preferences between workers typically holding part-time versus full-time contracts) also plays an essential part in explaining observed part-time pay penalties (Paul, 2016).

Some studies have assessed part-time/full-time wage differentials distinguishing between different types of part-time work, including working part-time with a few hours and more extensive part-time work (Paul, 2016) or being in a fixed-term versus permanent job position 
(Fernández-Kranz and Rodríguez-Planas, 2011). Most relevantly for the present paper, some scholars have looked at what happens when the change in the working time arrangement is not accompanied by a simultaneous change of the employer (Day and Rodgers, 2015; Fernández-Kranz and Rodríguez-Planas, 2011; Manning and Petrongolo, 2009). For instance, Manning and Petrongolo (2009) have found that hourly earnings of women shifting from a full-time to a part-time contract in the same firm remain virtually unchanged in a sample of 90,000 British women observed in the period 2001-2003. In contrast, the raw part-time wage gap is as high as $25 \%$ and reduces to $12.5 \%$ when individual-level characteristics are controlled for and to $2.5 \%$ when also occupation categories are taken into account. Parttime status and wages may thus also be related to firm and job-match specificities that, if uncontrolled, can confound the estimated earnings differentials between part-time and full-time working time arrangements.

Paul (2016) used survey data for German female workers over the period 1984-2011. The study found evidence of a wage penalty for short part-timers (i.e., weekly working hours between 5 and 15 hours) and a wage premium for long part-timers (i.e., weekly working hours in the range of 15-35 hours), after controlling for individual-, firm-, and job-level observable characteristics, individual-level fixed heterogeneity, and non-random switches to part-time positions. Using Australian survey data for the period 2001-2004, Booth and Wood (2008) have found that the wage differentials of (both male and female) part-timers shift from negative to positive after controlling for individual-, firm-, and job-level observable characteristics and unobserved individual fixed heterogeneity. Day and Rodgers (2015) have recently updated the study by Booth and Wood (2008) using a 12-year panel survey, and confirmed the presence of a premium for full-timers that switch to part-time work, but only if the switch is within the same firm. ${ }^{3}$

Some papers have departed from estimating average effects and tested whether parttime/full-time wage differentials vary across the wage distribution. Simon et al. (2017) have performed quantile regressions using survey data for Spain and found that part-time work tends to penalize low-qualified men located in the lower part of the wage distribution and high-qualified women located in the upper part of the distribution. Gallego Granados (2019) has instead found an opposite result from survey data on German women, whereby a parttime wage penalty emerges at the lower end of the wage distribution and a premium at the top of the distribution, while for workers that earn median wages they found no discernible

\footnotetext{
${ }^{3}$ Both Paul (2016) and Booth and Wood (2008) do not distinguish between changes in the working time arrangement that occur within the same firm from switches that also involve a simultaneous change of the employer.
} 
difference between part-time and full-time pay. ${ }^{4}$

There are also a few cross-country studies that report part-time premiums for some countries and penalties for others (Bardasi and Gornick, 2008; Matteazzi et al., 2014; O'Dorchai et al., 2007; Pissarides et al., 2005). ${ }^{5}$ Like most of the single-country studies surveyed above, these cross-country studies typically control for an ample set of covariates at the individual-, firm-, and job-level (e.g., occupational segregation), and for non-random sorting into parttime status using fully-specified parametric models with distributional assumptions.

As far as we know, the only estimates on part-time earnings differentials existing for Italy come from these cross-country studies, and results are somewhat mixed. While Matteazzi et al. (2014) and Pissarides et al. (2005) both point towards the presence of a wage premium, Bardasi and Gornick (2008) and O'Dorchai et al. (2007) show evidence for pay penalties associated with part-time work.

In particular, Matteazzi et al. (2014) have used survey data from the European Union Statistics on Income and Living Conditions for the year 2009 and conducted the analysis for Italy on a sample of around 8,000 women aged 25-59. They found a significant (but small) part-time premium. Pissarides et al. (2005) have used the European Community Household Panel Survey for six annual waves (period 1994-1999) and performed their analysis for Italy on a sample of around 7,000 women and men aged 16-64. They found significant and substantial wage premiums for part-timers, both males and females. The study by Bardasi and Gornick (2008) resorts to the Luxembourg Income Study data and uses a sample for Italy of around 5,000 women aged 25-59 observed in the year 1995. It finds instead significant wage penalties associated with part-time work. O'Dorchai et al. (2007) have resorted to the European Structure of Earnings Survey for the year 1995 and conducted the analysis on a sample of around 67,000 men employed in Italian private-sector firms with at least 10 workers. They have found significant wage penalties associated with male part-time work. Notice that none of these studies on Italy use fixed-effects methods to control for unobserved time-invariant individual and firm heterogeneity. Fixed-effect methods flexibly control for non-random selection into part-time status without resorting to distributional assumptions, and complement existing research based on fully-specified models.

Finally, using administrative matched employer-employee panel data on working careers

\footnotetext{
${ }^{4}$ This finding is in line with the one reported by Paul (2016). While Paul (2016) has distinguished between short and long part-time work, Gallego Granados (2019) has compared low-pay and high-pay parttime occupations. Both results are consistent with the view that part-time work is a very heterogeneous phenomenon, possibly polarized between "good" and "bad" jobs.

${ }^{5}$ For women, a part-time pay premium has been observed in Sweden by Bardasi and Gornick (2008), and in Austria and Italy by Matteazzi et al. (2014). For men, it has been observed in Denmark by O'Dorchai et al. (2007), and in Italy, Austria, and Greece by Pissarides et al. (2005).
} 
(INPS-WHIP), Pacelli et al. (2013) have investigated the presence of a "motherhood" wage penalty among Italian women over the period 1989-2003. Interestingly, they have found that a shift from a full-time to a part-time contract after becoming mothers is not associated with a reduction of the hourly wage, while a wage gap is observed if women are still working as full-timers after childbirth. They interpret the results by arguing that the high protection accorded to part-time jobs in Italy was preventing the emergence of any "motherhoodrelated" part-time wage gap. ${ }^{6}$

\section{Empirical model and identification issues}

As discussed in the previous sections, the part-time/full-time wage differential might be the result of many intervening factors: holding a contract stipulating a reduced number of hours per se is only one of them (Paul, 2016). To motivate the empirical model used below, clarify the nature of the estimated parameters, and discuss identification issues, it helps to quickly recap the many confounders at play.

A relevant fraction of the raw part-time wage penalty is accounted for by observable personal characteristics of the worker, such as his/her human capital (e.g., education and experience) or other individual characteristics (e.g., children). While these factors have a substantial effect on wages, at the same time, they are strong determinants of the decision to work part-time. For instance, part-time jobs are often associated with positions for loweducated or low-experienced individuals, which are associated with lower wages. Similarly, limitations to mobility and constrained schedules due to family commitments might force individuals to take on less favorable jobs, which might be part-time. However, once these observable personal characteristics of the worker are accounted for, part-time workers are still found to earn substantially less than full-timers.

Other dimensions that contribute to explaining a substantial fraction of the part-time wage penalty are job characteristics, including occupation, and workplace characteristics. There is significant job segregation associated with part-time work: low-skilled positions and fixed-term contracts are significantly more likely to be associated with part-time contracts compared to high-skilled positions and permanent contracts. Female segregation at the workplace also contributes significantly to explaining the part-time wage penalty (Mumford and Smith, 2009).

As reviewed earlier, a first strand of the literature has estimated part-time/full-time

\footnotetext{
${ }^{6}$ The WHIP data set is similar to ours, but refer to a much shorter, earlier period; more importantly, it is a 1:12 random sample from the worker universe. This makes the estimation of models with both worker and firm fixed effects virtually unfeasible.
} 
wage differentials by controlling for as many observable differences as possible, including individual, job, and workplace characteristics (Bardasi and Gornick, 2008; Ermisch and Wright, 1993; Matteazzi et al., 2014; Manning and Petrongolo, 2009; Mumford and Smith, 2009; Wolf, 2002). These studies estimate a "pure" effect of part-time work, insofar as they hold constant observable aspects that differ between part-time and full-time work. However, they are not necessarily able to identify the causal effect of holding a part-time contract. Other factors not attributable to working a reduced number of hours per se can determine the wage differential.

Some scholars have stressed the role of differences in work histories between part-time and full-time workers (Connolly and Gregory, 2009; Fernández-Kranz et al., 2015). Being employed part-time in previous years might lead to accumulating substantially less experience and (firm-specific) human capital compared to having worked full-time, thereby implying lower wages of part-time workers who have been holding part-time contracts for a long time.

A second set of studies have acknowledged that part-time workers might be different compared to full-time workers on time-invariant unobservable individual characteristics, such as ability, commitment to work, and energy. Such unobserved fixed heterogeneity explains a relevant part of the part-time penalty, which often disappears (or even transforms into a premium) once it is controlled for (Booth and Wood, 2008; Hirsh, 2005; Connolly and Gregory, 2009; Fernández-Kranz and Rodríguez-Planas, 2011). As highlighted by Paul (2016), while accounting for individual fixed effects appears essential to get closer to an estimate of the causal effect of part-time work, it also entails that such effect is estimated exclusively on those that switch from a full-time to a part-time position (or vice versa).

It is also crucial to account for unobserved fixed firm heterogeneity, including corporate culture, degree of firm-level collective bargaining, or corporate social responsibility, which might affect wages offered by the firm and its use of part-time contracts (Fernández-Kranz and Rodríguez-Planas, 2011). Accounting for unobserved fixed firm characteristics - beyond worker fixed effects - implies estimating the wage differential on those workers that switch from full-time to part-time work (or vice versa) while employed by the same firm, but ensures that the impact of part-time work abstracts from any confounding effects due to a contemporaneous change of employer.

However, after having controlled for both individual and firm fixed effects, some timevarying factors can still intervene in the decision (either by the employee or the employer) to switch working time arrangement, and, at the same time, be correlated with earnings changes (i.e., contemporaneous endogeneity; see also Aaronson and French, 2004, and Paul, 2016).

First, it is essential to control for possible changes in the job contract that might occur 
contemporaneously with the change in the working time arrangement. They include changes in the type of occupation (i.e., occupational upgrading) ${ }^{7}$ and duration of the work contract (i.e., passing from fixed-term to permanent contract). Having a child is another typical and relevant event (Connolly and Gregory, 2009; Paul, 2016). ${ }^{8}$ Similarly, the firm's decision to transform some of the workers' contracts from full-time to part-time can also be not random and time-varying. A typical situation in which contemporaneous endogeneity might emerge is when the firm experiences a period of crisis, during which it might convert selected groups of employees to part-time work schedules and contextually reduce their wages.

Given the above discussion, we estimate the following wage regression:

$$
\ln \left(w_{i j t}\right)=\alpha_{i}+\phi_{j}+\mu_{i j}+\beta P T_{i j t}+\gamma X_{i j t}+\epsilon_{i j t}
$$

The dependent variable, $w_{i j t}$, is the hourly wage of worker $i$ working in firm $j$ in year $t$. The term $\alpha_{i}$ is a worker fixed effect, capturing the time-invariant worker heterogeneity. The term $\phi_{j}$ is a firm fixed effect, capturing the time-invariant firm heterogeneity. The term $\mu_{i j}$ is a firm-worker match fixed effect, capturing time-invariant match heterogeneity (on this, see below). Our regressor of interest is $P T_{i j t}$. It is a dummy variable for the part-time contract. It is 0 if the worker holds a full-time contract and 1 if the worker holds a part-time contract. As highlighted by the subscripts of $P T_{i j t}$, we can observe the part-time status of a given worker across years and firms. Importantly, this means that we know whether a worker switches from a full-time to a part-time contract (or vice versa) while at the same employer, or after changing employer. The vector $X_{i j t}$ collects a variety of worker- and firm-level characteristics included as controls. Depending on the specifications, they can comprise the worker's migration status, age, occupation, contract duration (i.e., permanent versus temporary), tenure in the firm, total work experience, total experience in part-time work, the firm's size, sector of economic activity, and region, and year fixed effects. ${ }^{9}$ Depending on the specifications, the vector $X_{i j t}$ will also include controls for maternity events and demand shocks at the firm-level, or at the level of the local labor market, to account for potential problems of contemporaneous endogeneity outlined above. Finally, $\epsilon_{i j t}$ is the residual of the regression. Our parameter of interest is $\beta$, which measures the percentage wage differential

\footnotetext{
${ }^{7}$ Formal occupational downgrading within the same firm is illegal in Italy. In practice, the switch to a part-time arrangement might be associated with a professional deskilling, which cannot be observed from administrative data.

${ }^{8}$ It often happens that women ask for a reduction of working hours after having a child, which might have wage effects other than those related to the switch to a part-time contract.

${ }^{9}$ Note that we cannot explicitly account for workers' education as our data do not provide this information. However, this should not represent an issue as education is mostly time-invariant for those who are employed, and, therefore, largely accounted for by worker fixed effects (on this, see also Connolly and Gregory, 2009).
} 
between part-timers and full-timers that emerge net of the controls listed earlier.

We estimate Equation (1) by OLS using within-spell variation. ${ }^{10}$ Not only does this entail the removal of worker and firm fixed effects. It implies that we are also controlling for any fixed unobserved heterogeneity related to the job match (i.e., the employer-employee match). Match-specific fixed heterogeneity (embedded in $\mu_{i j}$ ) may include skills and knowledge of the worker that are particularly relevant to the firm, which likely influence both the wage and part-time status of the match. Crucially, removing worker, firm, and match fixed effects means that we estimate the part-time/full-time wage differential by using wage variation arising from switches from full-time to part-time contracts (or vice versa) of the same worker in the same firm.

In sum, we obtain an estimate of the part-time/full-time wage differential that is neither driven by selection into specific jobs and due to particular worker and firm observable characteristics (including work histories), nor by unobserved individual, firm, and job match fixed heterogeneity. Since we also control for contemporaneous endogeneity due to adverse conditions experienced by the firm, on the one hand, and entry into motherhood, on the other hand, the estimated $\beta$ identifies the causal effect of part-time work if one assumes that no other time-varying factors intervene in the decision (either by the firm or by the employee) to switch from a full-time to a part-time contract or vice versa.

\section{Data}

We use administrative data of the Italian Social Security System (INPS), which collect labor market histories for the period 1983-2015 of each employee working for at least one day in any private-sector firm in Italy. In the data, workers and firms are assigned unique identifiers, allowing us to track them longitudinally. It is also known in which firm a given worker is employed at each point in time. Hence, we have a longitudinal matched employer-employee data set on the universe of Italian private-sector employees over more than 30 years.

Worker information includes basic demographic characteristics: the worker's gender, age, and place of birth. Although imperfectly, we can also recover information related to maternity periods by exploiting INPS information on maternity leaves. As concerns information of the worker's job, we have data on yearly gross wages, number of days worked over the calendar year, type of occupation, contract duration (fixed-term versus open-ended contract), and whether the worker holds a part-time or full-time contract. All these variables are time-varying, that is, they can change from one year to the next, while at the same firm or following a change in employer.

\footnotetext{
${ }^{10}$ We refer to worker-firm combinations as "spells".
} 
Differently from most of the papers reviewed in Section 3, which base the distinction between employees working full-time and part-time by looking at how workers describe their employment situation or by establishing ex ante a specific hours threshold, in our data set, the contract itself neatly identifies the part-time status. Therefore, we can precisely separate part-timers from full-timers without resorting to arbitrary hours cut-offs. Thanks to the panel dimension of the data set, we can also compute the workers' experience in the labor market, as well as their experience in part-time work. Similarly, we can reconstruct the workers' tenure in the firm.

As for firms, we have information on general characteristics such as their location and industry. We can also construct variables related to the firms' workforce, such as their use of part-time work. Finally, INPS information on incorporated businesses could be matched to the financial information contained, for the same firms, in the AIDA data set (Bureau Van Dijk). The matching procedure was carried out using unique fiscal identifiers by the INPS data warehouse. This allowed us to retrieve firm-level financial information (e.g., revenues or value-added) from the yearly balance-sheets that firms are mandated to maintain and deposit within the system of the Chambers of Commerce (see Section 6 below). ${ }^{11}$

Although we do not directly observe working hours, we can precisely measure a worker's contractual hourly wage at each point in time. The hours of work stipulated in a full-time contract contain a sector, firm, and occupation-specific components. We have controls for each of these components in equation (1). We then need information on the number of hours stipulated by each part-time contract. The INPS data provides us with this information. Specifically, we know the exact proportion of hours of work stipulated by each part-time contract when compared to the corresponding contract for a full-time position, that is, a full-time position held in the same sector, firm, and occupation. ${ }^{12}$ Hence, our regression analyses allow us to estimate how the contractual hourly wage of a worker changes when moving from a part-time to a full-time position, or vice versa.

We conduct a basic cleaning of the data. First, we focus on individuals aged 15-64 (i.e., those within the typical working age). Second, we drop jobs with less than 16 paid weeks in a year in order to capture workers with a minimum of labor-market attachment. ${ }^{13}$ Third,

\footnotetext{
${ }^{11}$ The AIDA data set includes balance-sheet information on the universe of non-financial incorporated businesses. Since non-incorporated firms are not required to file detailed balance-sheets, they are not present in AIDA. Hence, analyses where we exploit balance-sheet information rely on part-time/full-time switches that occur within firms included in the INPS-AIDA matched data.

${ }^{12}$ This information is obtained from the INPS variable called "settimane utili".

${ }^{13}$ Notice that this restriction applies only to yearly observations. Therefore, if an individual works less than 16 weeks in a given year, we do not remove the entire block of panel observations corresponding to that individual. For robustness, we carried out several estimations for the case in which we do not apply this restriction and observed very similar results.
} 
to minimize measurement error in wages, we drop the top and bottom $1 \%$ in each yearly wage distribution, as well as any job reporting a number of paid days over the theoretical maximum in a year (equal to 312 days). Finally, for workers holding multiple jobs in the calendar year, we select the one with the highest wage. ${ }^{14}$

In our empirical analysis, we focus on the more recent, post-crisis period 2009-2015. The total number of observations in that period is 33,088,421. As shown in the bottom part of Table 1, there are over 1,5 million of women who switch from full-time to part-time contracts or vice versa within this period. As many as 792,079 of these switches occur within the same firm. These 792,079 observations are those on which we identify our effect of interest, that is, when we remove both worker and firm (and, consequently, match) fixed effects. As one can see from Table A.1 in Appendix A, many of these switches are from full-time to part-time contracts $(501,787)$, whereas switches from part-time to full-time arrangements are relatively less frequent (290,292 occurrences).

Worldwide, part-time jobs are typically held by women, and Italy is no exception. According to our data, about $42 \%$ of female employees were working part-time in the 2009-2015 period. As Table 2 shows, the proportion of part-timers among females steadily increased during our 33-year span. The share of part-timers among males was instead much lower: on average, only about $11 \%$ in the $2009-2015$ period. However, as for females, it steadily increased throughout our observation window (see Table B.1 in Appendix B). ${ }^{15}$

Finally, Table 6 reports the number of workers' transitions into part-time or full-time work differentiating among a variety of labor market segments, and Table A.2 in Appendix A reports summary statistics on observable worker-, job-, and firm-level characteristics for the different subsets of switchers. These two tables give additional information on the switchers. Switches within the same firm appear to be more likely in "good jobs" or "better matches". They are more preponderant among workers in prime-age or older-age categories, among natives, permanent workers, white-collar workers or managers, and workers in firms located in more prosperous areas (North-East and North-West), as well as those employed in medium and large companies. Among those who change working time arrangements within the same firm, average experience and tenure are higher. Finally, among those who switch from

\footnotetext{
${ }^{14}$ As an alternative, we randomly selected one job in case of multiple job holdings in the year, but this did not produce any significant change in our results.

${ }^{15}$ We have compared such statistics with data from the Labor Force Survey for Italy. While roughly comparable, the shares of part-time workers are systematically higher in INPS data compared to LFS data. Such discrepancy is likely linked to different population coverages in the two data sources. Most relevantly, the LFS also includes public-sector employees, where part-time work is substantially less widespread compared to the private sector. For instance, according to the Italian State General Accounting Department, the share of part-timers among females was only around $7 \%$ in the public sector in 2006. Moreover, the LFS is based on self-reported information, whereby workers might misreport information on their work contract.
} 
full-time to part-time work within the same firm, the proportion of women experiencing a maternity-leave event in the year is the highest, coherently with the fact that entering into parenthood is a crucial determinant of the workers' request to switch to a part-time contract. ${ }^{16}$

\section{Results}

\subsection{Main results}

Table 1 shows our main results derived from the estimation of Equation (1). Here we concentrate on the 2009-2015 period. Following the discussion in Section 4, we present different versions of the estimated part-time/full-time wage differentials, which gradually insert controls. All the estimations report robust standard errors clustered at the worker and firm (i.e., at the job match) level.

The first row of the table shows that there is a raw part-time/full-time wage differential of -0.233 . This is consistent with the other studies in the part-time literature, whereby substantial row part-time pay gaps are reported in many industrialized countries. In Model 2, we control for a series of worker-, firm-, and job-level observable characteristics, and year fixed effects. As for worker- and job-level controls, we include a cubic polynomial for the worker's age, a dummy for foreign-born workers, dummies for contract duration (i.e., permanent versus temporary), and dummies for occupation (divided into three classes: blue-collar worker, white-collar worker, and manager). As concerns firm-level controls, we include dummies for firm size (6 classes), industry (2-digit ATECO-2007 classification), and region (20 dummies). The wage penalty associated with part-time arrangements reduces to about $10 \%$. In accordance with previous studies, accounting for observed worker-, job-, and firm-level characteristics is essential to net out any effect due to selection into specific jobs and of particular categories of workers and firms into part-time work.

Since unobserved fixed firm heterogeneity is likely to confound the effect, in Model 3, we add firm fixed effects. The estimated part-time penalty reduces further to $4 \%$, thus pointing to the importance of netting out any wage effect due to unobserved firm specificities (e.g., differences in firm wage policies, firm-level bargaining, or corporate culture). Models with firm-fixed effects compare workers who share the same working environment; they, however, fail to adequately recognize that co-workers holding part-time instead of full-time contracts may be inherently different. In Model 4, we instead control for worker - and not firm - unob-

\footnotetext{
${ }^{16}$ Gathering this information is crucial for the robustness checks aimed at ensuring that results are not driven by selection bias and to explore the mechanisms behind. We thank two anonymous referees for having raised these issues.
} 
served fixed heterogeneity. The part-time penalty transforms into a statistically significant premium, equal to $1.9 \%$. Unobserved differences between workers typically holding parttime as opposed to full-time positions are thus crucial to be controlled for. Put together, the results from Models 3 and 4 tell us that both firm and worker unobserved heterogeneities are critical confounding factors. In Model 5, we estimate a version of Equation 1, which, in addition to time-varying controls of Model 2, removes both firm and worker fixed effects. The estimate shows that part-time contracts are associated with $4.6 \%$ higher hourly wages compared with full-time contracts.

Workers' labor market histories might also contribute to confounding the estimated parttime/full-time wage differential. In Model 6, beyond worker and firm fixed effects and observable characteristics, we add controls for the worker's tenure and tenure squared. In Model 7, we further add controls for total labor market experience and its square. ${ }^{17}$ Both models confirm a part-time premium just under 5\%. In Model 8, we further insert a control to explicitly account for experience in part-time work, measured as the number of years with a part-time contract since the first observation in the INPS data set. Again, the estimated part-time/full-time differential is stable (4.8\%).

In Section 2, we have pointed out that contemporaneous endogeneity can still hinder the identification of the effect of interest. In particular, we see two factors as particularly relevant: maternity and firm-level shocks. In Model 9, we include a dummy variable indicating whether the worker has been on maternity leave in the current year, which would capture as neatly as possible the event of childbirth. The estimated part-time/full-time differential is still positive and significant, at 3.9\%. In Model 10, we control for firm-level shocks by resorting to information on the firms' yearly balance sheets obtained from the AIDA data set (i.e., here we use the matched INPS-AIDA data set on non-financial incorporated companies). Productivity shocks are proxied by the firm-level value added per employee. ${ }^{18}$ The estimated part-time differential in the INPS-AIDA sample of incorporated businesses and their workers is still positive and significant, at $3.0 \%$.

After removing any confounding effects related to selection of part-time contracts into specific occupations and due to particular worker, job, and firm characteristics (including employees' work history), and after controlling for worker, firm, and match unobserved fixed heterogeneity and contemporaneous endogeneity stemming from maternity and firmlevel shocks, it emerges that part-time contracts are associated with a higher hourly wage compared with full-time contracts. This differential is in the range of 3 to $5 \%$ and is always

\footnotetext{
${ }^{17}$ Tenure is measured as the number of years the employee works in the firm, whereas total experience in the labor market is measured as the number of years since the first job (as observed in the INPS data).

${ }^{18}$ As an alternative, we considered revenues per worker, with little changes in the results.
} 
statistically significant. Furthermore, the evolution of the estimated wage differential to additional controls - from a raw part-time penalty of $23.3 \%$ to a significant part-time premium - indicates that the wage effect of part-time contracts per se is indeed mixed up with a large variety of confounding effects, which is crucial to net out.

Table 2 shows the evolution of the part-time/full-time wage differential over our 33-year span. From now on, we present estimates with the same set of controls in Model 8 of Table 1, that is, with worker, firm, and match fixed effects, together with time-varying worker-, firm-, and job-level controls including the full set of variables related to the employee's work history. ${ }^{19}$ Female part-timers experienced wage premia throughout our observation window. The difference was high in the early periods and constantly decreased over time, passing from as much as $32.7 \%$ in the $1983-1987$ period - when only $3.2 \%$ of female workers held part-time contracts - to $4.7 \%$ in the most recent $2009-2015$ span. $^{20}$

\subsection{Robustness I: contractual versus actual hours}

A notable feature of our data is the possibility to control for a large set of observable and unobservable worker-, firm-, and match-specific wage determinants. However, a potential limitation is that we do not observe actual hours of work. Only a few matched employeremployee data sets include information on actual hours worked at the individual level. When present, however, this information is typically more seriously contaminated by measurement errors than earnings data drawn from social security sources. In the following, we take various steps to provide an assessment of how unobserved variation in actual hours worked might impact on the estimated part-time wage premium.

While our data allow us to account for variation in the number of hours formally stipulated (ex-ante) by the part-time contract, they cannot account for (ex-post) variation in the actual number of hours worked by both full-timers and part-timers, for instance, due to contingent local- or firm-level economic conditions. As any overtime payments are included in the numerator of our earnings measure, a potential issue arises as to whether unobserved overtime or any other "extra" hours are differentially affected for part-timers and full-timers by business-cycle conditions or firm-level shocks. ${ }^{21}$

\footnotetext{
${ }^{19}$ For these and the following additional estimates, we also experimented with specifications in Models 9 and 10 of Table 1 and obtained unchanged results.

${ }^{20}$ Even though this paper focuses on women, we report some general estimates for males. In Table B.1 in Appendix B the picture is somewhat different from what emerges for women. While men experienced significant, yet decreasing, part-time premiums up to the early 2000s, in more recent years, the wage differential disappeared.

${ }^{21}$ Having data on contractual versus actual working hours would have allowed computing imputed actual working hours based on observable worker characteristics, as in Fernández-Kranz and Rodríguez-Planas (2011). In this method, however, workers with the same contractual hours and observable characteristics
} 
A related issue arises concerning involuntary part-time work, defined as a situation where the worker would prefer to work more hours, but she is only offered a part-time job. Involuntary part-timers are more prevalent in a slack labor market, with high unemployment. Somebody who may have to involuntarily switch to a part-time job, as a coping strategy to avoid losing her job, is likely to suffer from a lower hourly wage because of his/her reduced bargaining power. Alternatively, the same switch may entail an increase in the unit wage if compensating wage differential considerations prevail, that is, if the higher hourly wage is a compensation for the reduced number of hours, softening the drop in total labor income.

The concerns related to unobserved variation in hours should arguably be more relevant when the local economy, the sector, or the firm is affected by adverse demand shocks, and when the firm is less bound by formal practices and enforcement of labor contracts. To investigate the practical relevance of such concerns, we follow four strategies. First, we interact the dummy for part-time status with the local unemployment rate. Second, we look at the dynamics in revenues at a fine sectoral level to identify the subset of firms facing adverse demand shocks and for which variations in worked hours and switches to involuntary part-time work may have been more likely to occur. Third, we try to identify the subset of firms that have raised more intensively their use of part-time labor from one year to the next. When an unusual share of a firm's workforce switches from a full-time to a part-time position in any given year, this might indicate that the firm is facing a negative demand shock, and the switch to part-time work is demand-driven, that is, it is involuntary for the workers. Fourth, we explore part-time/full-time wage differentials in specific subgroups of workers where fraudulent practices of underreporting working hours of part-timers are unlikely. ${ }^{22}$

The results of these analyses are collected in Tables 3,4 , and 5 .

In Table 3, we find that the part-time premium is reduced in the presence of high regional unemployment, as shown by the negative interaction term. ${ }^{23}$ When a region undergoes a

are imputed the same actual hours, thereby disregarding idiosyncrasies in the firm's demand shocks, which are a crucial reason why there might emerge discrepancies between actual and contractual hours among part-timers.

${ }^{22}$ Fernández-Kranz and Rodríguez-Planas (2011) report that the practice of underreporting working hours for part-timers is widespread in Spain. We have tried to directly assess whether this was the case for Italy. We have checked several surveys on Italian workers, including the Labor Force Survey (LFS), the Time Use Survey (TUS), and the European Working Condition Survey (EWCS). Unfortunately, there are no variables available to us that make it possible to directly observe whether part-time workers systematically work more hours than the hours stipulated by their contracts. However, some indirect evidence suggests that, in Italy, the practice of differential underreporting of working hours by part-time status might not be a significant issue. The ratio of actual hours worked by part-timers and full-timers computed on the LFS is virtually the same compared to the share of contractual hours worked by part-timers and full-timers in the INPS data.

${ }^{23}$ In this case, we focus on the 2005-2015 period rather than the 2009-2015 period to exploit variation in regional unemployment rates in pre- and post-Great Recession years. 
favorable business cycle, and unemployment is low, hours of work and overtime payments are typically higher. The estimated part-time premium may be partly related to a greater variation of hours worked among part-timers in regions with high labor demand. However, the magnitude of this effect is negligible: the estimates imply that the part-time premium is 0.0399 with an unemployment rate of $3.7 \%$ (10th percentile in the distribution of unemployment) and falls to 0.0397 when unemployment is at $13.7 \%$ (90th percentile).

In the first panel of Table 4, we split the sample according to whether the job is held in a firm experiencing a large - as opposed to a small - change in the sectoral product demand. ${ }^{24}$ A large (small) shock is defined as being above (below) the median yearly change in the real $(\log )$ revenues at the sectoral level, defined using 5-digit ATECO-2007 industry classification. The estimated part-time premium is hardly sensitive to the size of the industry product demand shocks, again suggesting that variation in unobserved hours of work does not drive our results.

In the second panel of Table 4, we proxy a firm's demand situation by relying on firmlevel variation in its use of part-time labor. We compute, for each firm, indicators capturing variation in the intensity of part-time work among the firm's workforce (e.g., any switch in the number of hours contractually defined by the workers' labor contracts). ${ }^{25}$ Then, we separately estimate part-time/full-time wage differentials on the sub-sample of firms where the one-year lagged change in the firm-level use of part-time work is above the 90th median change in the sample. We also fit a similar model on the sub-sample of firms with a smaller increase in the part-time intensity, which we set at the 50th percentile in the distribution of the part-time intensity change in the overall sample. We rely on the lagged firm-level change to exclude that this measure is simply mechanically picking up the current switch in the part-time status of worker $i$, that is, $P T_{i j t}$ in Equation (1). Moreover, to make the firm-level change in part-time intensity more meaningful, we limit this analysis to firms with at least 15 employees. Consistently with the results discussed earlier, we do not find any sizeable difference in the estimated part-time premiums in these two sub-samples.

In Table 5, we report our reference estimate of part-time/full-time wage differentials in two specific sub-samples where the practice of differential underreporting of working hours by part-time status is unlikely. ${ }^{26}$ In particular, we have enough within-firm switchers to run

\footnotetext{
${ }^{24}$ As here demand shocks are defined as industry-specific, we can rely on the entire INPS data set, containing both incorporated and non-incorporated businesses, rather than on the smaller INPS-AIDA data set that we need to use when examining the relevance of firm-level demand shocks.

${ }^{25}$ We do so by computing the firm-level change in the ratio between two INPS variables: the number of "equivalent weeks" and the number of paid weeks.

${ }^{26}$ It should be noticed that, while off-the-book payments are not uncommon in Italy, they are typically not recorded in administrative data, as the latter cover regular wage payments in jobs for which the employer
} 
our preferred econometric specification even in the narrowly-defined cells made of workers who are prime-age (we further isolate workers aged 35-45 and 45-50), native, blue-collar, with a permanent contract, working in large firms, in the manufacturing sector, and the NorthWest of Italy. These are arguably the typical contexts where the combination of strong unions' presence, managerial practices, and the more prevalent civic and pro-law cultural traits (e.g., compared to the South of the country) make the monitoring and enforcement of labor contracts more likely and, conversely, misreporting or other informal practices less widespread. Even in these specific cells, estimates point to a significantly positive, near to the average value, part-time premium.

Overall, the bulk of the evidence reported in this section weighs against the concern that variation in unobserved actual hours of work may play any significant role in our estimates.

\subsection{Robustness II: selection and heterogeneity}

While controlling for worker, firm, and match fixed effects is crucial to obtain a more robust estimate of the actual part-time/full-time wage differential, it also entails that the wage effect of part-time contracts is identified on the specific sample of workers who change working time arrangement within the same firm, thereby causing possible selection bias. As highlighted in Section 5, those who switch working time arrangements within the same firm may be typically associated with "good jobs" (e.g., prime-age, native-born, white-collar, permanent workers). Changes in working time arrangements with the same employer might thus be more likely granted to workers who are "important" for the firm, for instance, those with good employer-employee matches. Similarly, often women ask for a switch to a part-time contract following maternity, and those who see their requests fulfilled might be those more productive and strongly attached to the labor market. Observed part-time premiums might thus be driven, at least in part, by these selection issues.

In the following, we pursue a variety of robustness checks to explore the relevance of these selection concerns. First, we estimate part-time/full-time wage differentials in many different subgroups of workers based on available observable worker-, firm-, and job-level characteristics. We then explore the part-time wage effect for workers with different degrees of tenure in the firm and experience in the labor market, which - albeit imperfectly - reflect the "importance" of the worker for the employer. We check for differentiated effects by degree of experience in part-time work, which might command wage changes at the moment of the switch. Resorting to INPS information on maternity leaves, we also investigate parttime/full-time differentials by maternity status. Finally, we more directly tackle the issue of

pays social security contributions. Hence, in principle our wage variable is not affected by this type of underreporting practices. 
selection by unobservable worker ability by partitioning workers in terms of proxies of these abilities, obtained before-hand through AKM-style estimates of worker fixed effects (Abowd et al., 1999) from workers' histories before 2009. All these robustness checks are possible thanks to the large dimension of our data, which allows us to investigate how wages differ between full-time and part-time contracts for various - even narrowly-defined - groups of workers.

As in Table 1, here we focus on the more recent 2009-2015 period. The results are collected in Tables from 6 to 9 .

In Table 6, we re-estimated Model 8 of Table 1 separately for 22 different categories of workers. We begin by splitting the sample by workers' age groups (rows 1 to 4 of Table 6). The motivations for undertaking part-time work might differ along the life cycle, particularly in consideration of family commitments and circumstances. We then look at whether the inclusion/exclusion of specific groups of workers, such as foreign-born or workers with temporary contracts, might have any detectable impact on our results, possibly on account of their lower bargaining power (rows 5 to 8 ). Next, we split the sample according to three major occupation groups (blue-collar workers, white-collar workers, and managers), once again to document the existence of any differential part-time premium related to the specificities of these occupational profiles (rows 9 to 11). ${ }^{27}$ We then proceed by considering the sub-sample of workers employed in firms of different sizes, which might also differently use and reward part-time work (rows 12 to 16). For similar reasons, we split the sample according to whether the job is held into a manufacturing or service firm (rows 17 and 18). Finally, recognizing the large territorial disparities that characterize the country under consideration, we also look at the existence of any substantial differences in the wage differential by part-time status in different macro-areas (North-East, North-West, Center, and South of Italy, rows 19 to 22). A casual look at the table reveals that a positive part-time wage premium is found in any of the considered partitions and that it is always largely statistically significant. What is more notable is that the estimated part-time premium varies extremely little across the groups, although many of them might be regarded as structurally different in terms of preferences, endowments, and constraints. A part-time premium that is virtually invariant across so many observable characteristics provides an indirect indication that a similar premium would be found were it possible to partition the sample according to unobservable characteristics.

In Table 7, we re-estimated Model 8 of Table 1 for split samples by degree of tenure, experience, and experience in part-time work. We split the sample between high-tenure and low-tenure workers as those above and below median workers' tenure. Similarly, we divide

\footnotetext{
${ }^{27}$ Unfortunately, the data do not allow us to observe more detailed occupational groups.
} 
high-experienced and low-experienced workers as those above and below median workers' experience. Finally, we divide the sample between workers with no experience in part-time work or some experience in part-time work. As for the other subgroups in Table 6, in this case, too, it emerges a significantly positive part-time/full-time wage differential. Again, the estimated premium is very stable and in line with the average effect, reflecting the part-time premium is essentially invariant to employees' work history and possible selection concerns due to switches granted to "more important" workers.

In Table 8, we run separate regressions based on women's maternity status. We split the sample between women who have never been on maternity leave during the 2005-2015 period and women who have been at least once on maternity leave during the same period. Although indirectly, this captures the presence of young children in the household. The results show two things. First, a significantly positive part-time premium emerges for both categories of women. Notably, it is $3.2 \%$ - slightly lower than the average estimate - on women who did not experience maternity in recent years, indicating that selection concerns related to maternity highlighted above do not have a major role in our results. Second, a substantially higher part-time premium is found for those who experienced maternity, equal to $8.1 \%$. While this might be linked to more productive women asking and being granted a switch to part-time arrangements following maternity, it is also consistent with more generous legal provisions accorded to part-time mothers (see the discussion below on this).

Finally, Table 9 presents the estimated part-time/full-time differentials separately by AKM worker effects. This is a more direct way to check whether the observed part-time premium could be driven by "better workers" being more likely to ask (and be granted) switches to part-time contracts. Using the method in Abowd et al. (1999), we have first estimated worker effects from AKM regressions over the period 2005-2009, whereby wage regressions with worker and firm fixed effects are used to estimate workers' earning potentials depurated from firm-specific wage components (e.g., firm specificities in wage policies). This worker effect is commonly used as a proxy for the underlying individual productivity of the worker. We then merged the estimated AKM effects on the 2009-2015 portion of the sample. On the merged data, we then estimated the part-time/full-time wage differential for lowand high-productivity workers, corresponding to the bottom and top 25th percentiles of the AKM worker effects distribution, respectively. As one can see from the table, a significant part-time premium - in line with the average effect - again emerges in both cases, even in the opposite direction compared to what selection issues would entail. A slightly higher part-time premium is indeed found in association with less productive workers $(5.2 \%$ versus $3.4 \%$ ). This more direct check suggests that selection related to workers' (unobservable) 
productivity is not driving our results. ${ }^{28}$

In sum, the separate analyses by many population subgroups point to a substantial uniformity of the estimated part-time premium across all subgroups. Even for employees with different observed work histories (tenure, experience, and experience in part-time), the estimated part-time premium is very similar. A part-time premium emerges regardless of maternity status and individual productivity levels. Overall, this points to the fact that selection issues do not have any significant role in explaining the observed part-time premium. ${ }^{29}$

\subsection{Mechanisms}

In this subsection, we explore possible mechanisms behind the observed part-time premium. The numerous robustness checks presented earlier point to a part-time premium neither driven by variation in unobserved actual hours of work nor by selection issues. What emerges instead is a pervasive premium across all segments of the labor market. Such pervasiveness of part-time premiums must then be rooted in something that affects the worker population across the board.

The protective nature of legal provisions associated with part-time contracts - whereby sectoral- and firm-level collective agreements are allowed to grant more generous economic treatments to part-timers-, the functioning of the Italian labor market, and, above all, its system and practices of industrial relations seem the key culprits. The Italian labor market features a relatively high amount of wage rigidities, mostly owing to the prevalent role of sector- and firm-level collective bargaining (e.g., Devicienti et al., 2019). A form of rigidity that is particularly relevant to our context is the presence of wage components (e.g., bonuses and other monetary benefits) that are distributed in absolute amounts (i.e., non-proportional to hours worked). This is partly due to the egalitarian wage policies typically pursued by unions and their efforts to protect the weaker segments of the labor market, including women on part-time work. Some wage components bargained at the individual level, or unilaterally

\footnotetext{
${ }^{28}$ Table A.3 in Appendix A reports the results for the probability of changing the working time arrangement within the same firm (first panel) and switching from a full-time to a part-time contract within the same firm (second panel) by AKM worker effects deciles. As one can see from the table, there is no detected pattern that high-productivity workers have higher switching probabilities. While being sometimes significant, the coefficients are very small in magnitude (they range between +0.0007 and -0.0069 ). This suggests that changes in working time arrangements within the same firm (i.e., those on which we identify the parttime/full-time wage differential) are essentially independent of workers' intrinsic productivity levels.

${ }^{29}$ Notably, we do not detect part-time penalties in any of these subgroups, even among the most disadvantaged segments of the labor market. In particular, a part-time premium - even higher than the average - also emerges for foreign-born and temporary workers. This finding is in sharp contrast with the one reported for Spain by Fernández-Kranz and Rodríguez-Planas (2011), whereby a part-time penalty is found for temporary workers once individual and firm fixed effects are removed.
} 
granted by employers, may also be not entirely proportional to hours. Even small amounts of bonuses paid in absolute (i.e., quasi-fixed) amounts would end up favoring workers switching to part-time contracts.

We pursue three types of analyses that corroborate the empirical relevance of such a mechanism. First, higher benefits associated with part-time contracts due to legal provisions should be reversible, that is, should be strictly linked to the work contract. Therefore, one would expect that a switch from a full-time to a part-time contract should have a roughly similar, but opposite in sign, effect compared with the reverse switch from a part-time to a full-time arrangement. Second, if these more generous conditions associated with part-time contracts materialize in absolute amounts, switches to a short part-time schedule should command a higher premium than switches to a long part-time schedule. Third, rent-sharing within the firm should also favor part-time workers. This, too, is to be expected if at least some of the productivity-related bonuses are distributed to the firm's workforce nonproportionally to hours worked. Tables 10, 11, and 12 provide some first evidence that these mechanisms are at play. As usual, all these estimates include the same set of controls in Model 8 of Table 1, thereby presenting within-spell estimates.

Table 10 shows the wage effect of the two possible directions of switches: from full-time to part-time work and from part-time to full-time work. The estimated wage impact of a switch to part-time work is significantly positive (3.0\%), whereas the reverse switch from part-time to full-time is negative and significant at any conventional level $(-1.4 \%)$. In Table 11, we have first differentiated between short (defined as below 15 hours per week) and long part-time work (more than 15 hours per week). We have then adopted a more fine categorization and differentiated between short (again defined as below 15 hours per week), medium (between 15 and 28 hours), and long part-time work (above 28 hours). The results show that a significant part-time premium emerges in all these cases. However, the highest premium is associated with short part-time work $(13.4 \%)$, which decreases to $6.1 \%$ in medium part-time work, and $2.3 \%$ in long part-time contracts.

Finally, Table 12 shows results concerning within-firm rent-sharing effects. We leverage the empirical literature on rent-haring (e.g., Card et al., 2014) and run regressions to investigate how firms distribute firm-level productivity shocks among their full-time and part-time workers. Here, we use the INPS-AIDA matched data set, where information on each firm's yearly balance-sheets is available. Specifically, we estimate a version of Equation (1) that beyond controlling for the firm-level productivity, defined as the firm's yearly value added per worker, also includes its interaction with the part-time dummy. The significant and positive interaction coefficient suggests that firm-level productivity shocks are distributed to workers in quasi-fixed amounts (i.e., productivity-related wage bonuses are non-proportional 
to hours), thus favoring part-time workers. We also experimented with measures of a firm's quasi-rent per worker as in (Card et al., 2014), defined as value added per worker net of the opportunity cost of labor and capital. ${ }^{30}$ The results were very similar.

As discussed earlier, a possible explanation of observed part-time premiums might be related to compensating-differential mechanisms. Those relating to commuting costs are a typical example, whereby a part-time premium emerge to compensate for the higher weight of commuting costs in reduced working time schedules. In Table 13, we have verified such a mechanism by exploring part-time/full-time differentials based on the workers' commuting status. We have identified workers as commuters (non-commuters) if their municipality of residence is different from (equal to) the municipality where the job is located. We experimented with the exclusion of the major Italian cities for this exercise, with little differences for the results. As one can see from the table, there are no discernible differences in part-time premiums by commuting status. It is even slightly higher among non-commuters than commuters $(4.8 \%$ versus $4.5 \%)$. Compensating-differential mechanisms related to commuting thus do not seem to play any significant role in explaining the observed part-time premium. Other forms of compensating differentials are still possible. However, one would expect them to be differently relevant to the various subgroups of the worker population, which might be characterized by different preferences, endowments, and constraints. However, as discussed earlier, we find little evidence that the wage premium is heterogeneous across subgroups.

\section{Conclusions}

In this paper, we have used matched employer-employee data on the universe of Italian private-sector female employees over 33 years and analyzed the costs for employers, in terms of wage differentials, of transforming a work contract from full-time to part-time. Our research aim motivated from the fact - both reported in official statistics and by anecdotal evidence - that employers are often reluctant to concede switches to part-time arrangements. Assessing the reasons behind such reluctance required estimating a part-time/full-time wage differential that came as close as possible to the effect of working reduced hours per se, as depurated as possible from potential confounding effects.

We therefore estimated part-time/full-time wage differentials by eliminating worker, firm, and match fixed effects while controlling for a large number of worker-, firm-, and job-level time-varying characteristics, including employees' work history. We also controlled for non-

\footnotetext{
${ }^{30}$ The opportunity cost of labor is defined as the average industry by local labor market wage where the worker is employed. The cost of capital is obtained after applying an Italian estimate of the user's cost of capital to the stock of fixed assets reconstructed with the perpetual inventory methods. See (Card et al., 2014) for the details.
} 
random changes in working time arrangements due to maternity and local-, sectoral-, and firm-level demand/productivity shocks. We have conducted a large variety of robustness checks aimed at addressing two major concerns, namely, the fact that we did not observe ex post variations in actual hours of work and selection issues. We finally pursued several analyses to better gauge mechanisms behind the observed results. In particular, by matching balance-sheet information from the AIDA data set, we were able to control for critical firm-side events such as productivity/demand shocks and to explore the presence of rentsharing dynamics associated with part-time contracts, thus shedding new light on potential mechanisms for the part-time wage premium.

The results point to significant and pervasive part-time premiums for females, which, while declining, persist until recent years. The separate analyses by many population subgroups analyzed point to a substantial uniformity of the estimated premium across all subgroups. Even for workers with different observed work histories (in relation to tenure, experience, and experience in part-time), the estimated part-time premium was very similar. The same happened when we partitioned workers according to proxies of their productivity levels. While a somewhat higher part-time premium was found in association with maternity, a significant part-time premium nevertheless emerged also for women not experiencing childbirth. The part-time premium is not irreversible, but symmetrically linked to the transition: there is a premium in the switch from full-time to part-time work and a penalty in the switch from part-time to full-time work. A significant part-time premium emerges irrespectively of the type of part-time work schedule. Notably, part-time work with short hours is associated with a substantially higher premium compared to part-time work with extended hours. Finally, it appears that rent-sharing dynamics favor part-timers, who end up receiving a slightly higher share of the rents generated at their employers compared with full-timers.

What could drive these results? The Italian labor market features a relatively high amount of wage rigidities, mostly owing to the prevalent role of sector- and firm-level collective bargaining (Devicienti et al., 2019). In particular, while the Italian labor legislation dictates that part-timers must receive the same monetary and non-monetary treatments as comparable full-timers, it also explicitly allows sectoral- and firm-level agreements to provide more generous economic treatments to part-timers (Matteazzi et al., 2014). Reversible premiums, strictly linked to the work contract, are coherent with the part-time premium being commanded by institutional dynamics. Such a pervasiveness in the economy provides further support to the view that the observed part-time wage premiums are likely rooted in the institutions and practices that, across the board, characterize the country's system of industrial relations and wage bargaining. Furthermore, the high part-time premium associated with 
maternity is in line with the Italian labor legislation, whereby legal provisions concerning part-time work are particularly generous with part-time mothers (Pacelli et al., 2013). Declining part-time premiums are coherent with developments in wage bargaining institutions. Starting from the mid-1990s, the Italian labor market underwent a constant (if slow) trend towards a general liberalization and modernization, aimed at removing labor market rigidities, thereby improving the connection of wages to underlying workers' productivity and the overall allocative role of wages. Gradually over time, sectoral collective bargaining may have incorporated these tendencies also in the case of part-time work. However, even nowadays, unions try to protect what are seen as weak segments of the labor force. That these groups typically include part-time women (especially mothers) is in line with our findings that a part-time wage premium is still observed for females, especially after childbirth.

A common form of labor market rigidity, whereby part-time premiums emerge, is the presence of wage components, such as bonuses and other monetary gratifications, that are distributed in fixed amounts, that is, not proportionally to hours worked. Some wage components bargained at the firm-level, or unilaterally granted by employers, may also be not entirely proportional to hours, thereby favoring workers switching to part-time contracts. Higher premiums associated with short part-time contracts as well as rent-sharing dynamics favoring part-timers are indications that these mechanisms are also at play.

Our paper does not claim that these are the only or even the primary channels. Our more limited objective is to show that these specific channels have a role and contribute to the detected wage premium of part-time workers. We have also explored the existence of compensating-differential mechanisms related to work commuting, but these did not appear to have any detectable bearing on the observed part-time premium. Of course, other forms of compensating differentials are still possible. However, one would expect them to be differently relevant to the various subgroups of the population, which might be characterized by different preferences and constraints. However, the little evidence that the wage premium is heterogeneous across subgroups seems to suggest that such mechanisms might not play a significant role in explaining observed part-time premiums. Other channels, possibly related to structural changes in the demand and supply of part-time jobs, might have also been at play. While not having tested them directly, we could not exclude that - beyond the "institutional explanation" - the interplay between demand and supply could have influenced the evolution of part-time/full-time wage differentials in past and recent years.

In sum, the higher wage costs associated with part-time work, coupled with its detrimental effect on firm productivity that we documented elsewhere (Devicienti et al., 2018), contributes to explaining the firms' reluctance to concede part-time positions to employees asking for them. 
There are some important policy implications from these findings. Tax reliefs may be useful to overcome the firms' double disincentive (productivity losses and higher labor costs) to offer part-time positions. These rebates could be targeted to people in real need (e.g., involved in childcare or educational commitments), namely people who would voluntarily switch to a part-time position, were they given the option. Also, institutional reforms making wages more aligned to workers' productivity may contribute to raising the number of people successfully obtaining part-time positions when asking for them - a hitherto unnoticed benefit from such reforms.

The mechanisms that we have highlighted may matter also for the part-time/full-time differentials estimated in other countries and should be further investigated by future research, possibly relying on data sets with rich information on both the worker and the firm side. On the one hand, a consensus has not yet been reached on whether a premium or a penalty prevails in which country and under which institutional circumstances. On the other hand, many EU countries share similar collective bargaining institutions and industrial relations as Italy's. 







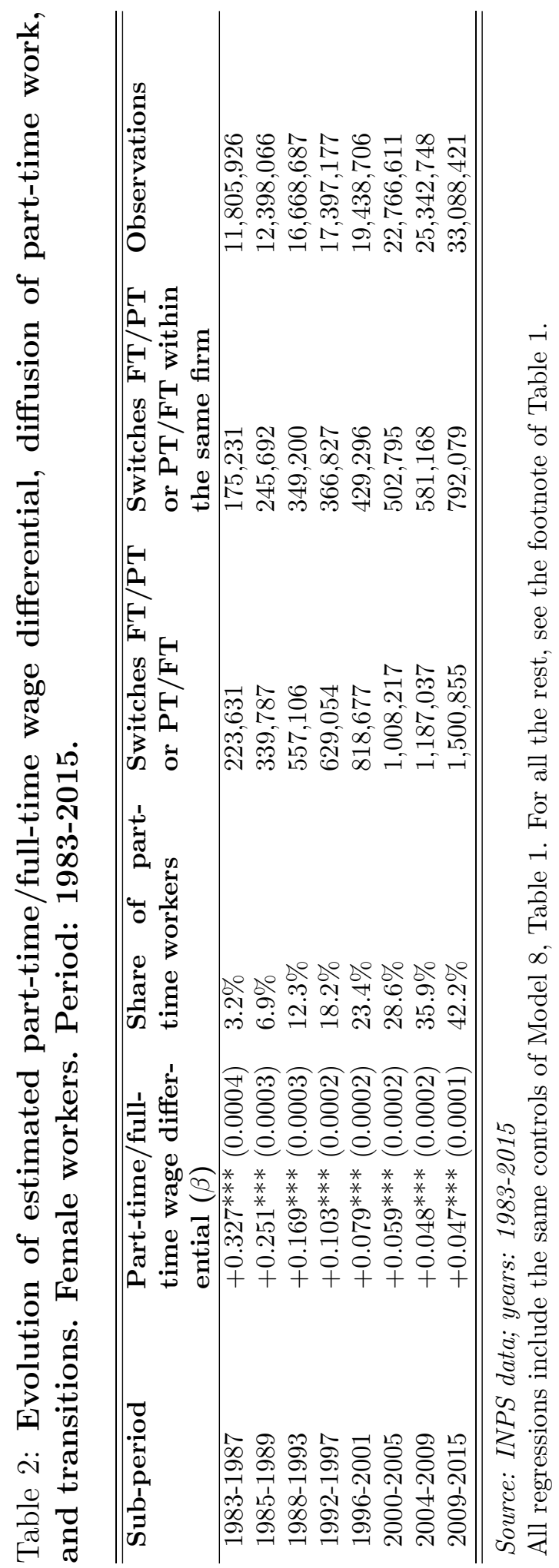


Table 3: Estimated part-time/full-time wage differential and potential variation in hours worked related to local labor market conditions. Female workers. Period: 2005-2015

\begin{tabular}{lc}
\hline \hline Part-time work & $+0.040^{* * *}$ \\
Regional unemployment rate & $(0.0002)$ \\
& $-0.002^{* * *}$ \\
Part-time work * regional unemployment rate & $(0.0000)$ \\
& $-0.0001^{* * *}$ \\
& $(0.0000)$ \\
\hline \hline
\end{tabular}

Source: INPS data; years: 2005-2015

This regression includes the same controls of Model 8, Table 1. For all the rest, see the footnote of Table 1 .

Table 4: Estimated part-time/full-time wage differential and potential variation in hours worked related to sectoral and firm-level demand shocks. Female workers. Period: 2009-2015.

\begin{tabular}{|c|c|c|}
\hline \multicolumn{3}{|c|}{ Firms below/above median change in log revenues at 5 -digit sectoral level } \\
\hline & Firms below median change & Firms above median change \\
\hline Part-time work & $+0.044^{* * *}(0.0002)[16,022,953]$ & $+0.048^{* * *}(0.0002)[16,036,935]$ \\
\hline \multicolumn{3}{|c|}{ Firms with high or very high lagged increase in firm-level share of part-time workers } \\
\hline Part-time work & $\begin{array}{l}\text { Firms above 50th percentile change } \\
\quad+0.046^{* * *}(0.0004)[8,407,245]\end{array}$ & $\begin{array}{l}\text { Firms above 90th percentile change } \\
\quad+0.038^{* * *}(0.0012)[1,174,132]\end{array}$ \\
\hline
\end{tabular}

Source: INPS data; years: 2009-2015

All regressions include the same controls of Model 8, Table 1. All regressions are run on split samples. In square brackets, the number of observations. For all the rest, see the footnote of Table 1.

Table 5: Estimated part-time/full-time wage differential in contexts with likely low discrepancy between part-time contractual and actual hours. Female workers. Period: 2009-2015

\begin{tabular}{ll}
\hline \hline Context & $\begin{array}{l}\text { Part-time/full-time } \\
\text { wage differential }(\beta)\end{array}$ \\
\hline $\begin{array}{l}\text { Workers aged (35-45], native-born, with a permanent contract, } \\
\text { blue-collar, in firms with }>250 \text { employees, located in North-West, }\end{array}$ & \\
operating in manufacturing sector & \\
\hline $\begin{array}{l}\text { Workers aged (45-50], native-born, with a permanent contract, } \\
\text { blue-collar, in firms with }>250 \text { employees, located in North-West, }\end{array}$ & \\
operating in manufacturing sector & \\
\hline \hline
\end{tabular}

Source: INPS data; years: 2009-2015

All regressions include the same controls of Model 8, Table 1. All regressions are run on split samples. In square brackets, the number of observations. For all the rest, see the footnote of Table 1. 





Table 7: Tenure, experience, experience in part-time work. Female workers. Period: 2009-2015

\begin{tabular}{lll}
\hline \hline Status & $\begin{array}{l}\text { Part-time/full- } \\
\text { time wage differ- } \\
\text { ential }(\beta)\end{array}$ & Observations \\
\hline High-tenure & $+0.044^{* * *}(0.0002)$ & $16,605,422$ \\
Low-tenure & $+0.049^{* * *}(0.0002)$ & $16,482,999$ \\
\hline High-experience & $+0.045^{* * *}(0.0002)$ & $16,622,534$ \\
Low-experience & $+0.051^{* * *}(0.0002)$ & $16,465,887$ \\
\hline No experience in part-time work & $+0.059^{* * *}(0.0002)$ & $13,973,040$ \\
Some experience in part-time work & $+0.039^{* * *}(0.0002)$ & $19,115,381$ \\
\hline \hline
\end{tabular}

Source: INPS data; years: 2009-2015

All regressions include the same controls of Model 8, Table 1. All regressions are run on split samples. High- and low-tenure workers are defined as those above and below median workers' tenure, respectively. High- and low-experienced workers are defined as those above and below median workers' experience. "No experience in part-time work" and "some experience in part-time work" are computed using the amount of experience in part-time work accumulated by 2005 (or by the first panel observation after that year). For all the rest, see the footnote of Table 1.

Table 8: Maternity. Female workers. Period: 2009-2015

\begin{tabular}{lll}
\hline \hline Status & $\begin{array}{l}\text { Part-time/full- } \\
\text { time wage differ- } \\
\text { ential }(\beta)\end{array}$ & Observations \\
& $+0.032^{* * *}(0.0001)$ & $24,595,481$ \\
& $+0.081^{* * *}(0.0003)$ & $8,242,278$ \\
\hline Never on maternity leave & & \\
\hline
\end{tabular}

Source: INPS data; years: 2009-2015

All regressions include the same controls of Model 8, Table 1. All regressions are run on split samples. "Never on maternity leave" and "at least once on maternity leave" refer to period 2005-2015. Therefore, the first status implies that the worker has never been on maternity leave between 2005 and 2015, whereas the second status means that the worker has been at least once on maternity leave in that time period. For all the rest, see the footnote of Table 1 .

Table 9: AKM worker effects. Female workers. Period: 2009-2015

\begin{tabular}{lll}
\hline \hline Status & $\begin{array}{l}\text { Part-time/full- } \\
\text { time wage differ- } \\
\text { ential }(\beta)\end{array}$ & Observations \\
\hline Bottom 25th percentile AKM worker effects & $+0.052^{* * *}(0.0003)$ & $6,402,957$ \\
Top 25th percentile AKM worker effects & $+0.034^{* * *}(0.0003)$ & $6,440,373$ \\
\hline \hline
\end{tabular}

Source: INPS data; years: 2009-2015

All regressions include the same controls of Model 8, Table 1. All regressions are run on split samples. AKM worker effects are derived from AKM regressions with two-way fixed effects computed over the period 2005-2009. For all the rest, see the footnote of Table 1. 
Table 10: Switches from full-time to part-time work versus switches from part-time to full-time work. Female workers. Period: 20092015

\begin{tabular}{lc}
\hline \hline Direction of switch & $\begin{array}{l}\text { Part-time/full- } \\
\text { time wage differ- } \\
\text { ential }(\beta)\end{array}$ \\
\hline Switch from full-time to part-time work & $+0.030^{* * *}(0.0002)$ \\
Switch from part-time to full-time work & $-0.014^{* * *}(0.0002)$ \\
\hline
\end{tabular}

Source: INPS data; years: 2009-2015

The regression includes the same controls of Model 8, Table 1. For all the rest, see the footnote of Table 1 .

Table 11: Short versus long part-time work. Female workers. Period: 2009-2015

\begin{tabular}{lr}
\hline \hline Type of part-time work & $\begin{array}{l}\text { Part-time/full- } \\
\text { time wage differ- } \\
\text { ential }(\beta)\end{array}$ \\
\hline Model 1 & $+0.121^{* * *}(0.0003)$ \\
\hline Short part-time work (less than 15 hours per week) & $+0.043^{* * *}(0.0001)$ \\
\hline Long part-time work (more than 15 hours per week) & \\
\hline Model 2 & $+0.134^{* * *}(0.0003)$ \\
\hline Short part-time work (less than 15 hours per week) & $+0.061^{* * *}(0.0002)$ \\
Ledium part-time work (between 15 and 28 hours per week) & $+0.023^{* * *}(0.0002)$ \\
\hline
\end{tabular}

Source: INPS data; years: 2009-2015

All regressions include the same controls of Model 8, Table 1. For all the rest, see the footnote of Table 1 .

Table 12: Rent-sharing. Female workers. Period: 2009-2015

\begin{tabular}{lr}
\hline \hline Part-time work & $+0.010^{* * *}(0.0018)$ \\
(log) Value added per worker in the firm & $+0.022^{* * *}(0.0001)$ \\
Part-time work * $(\log )$ value added per worker in the firm & $+0.003^{* * *}(0.0002)$ \\
\hline & Observations: $18,728,046$ \\
\hline
\end{tabular}

Source: INPS-AIDA data; years: 2009-2015

The regression includes the same controls of Model 8, Table 1. For all the rest, see the footnote of Table 1 . 
Table 13: Commuting. Female workers. Period: 2009-2015

\begin{tabular}{lll}
\hline \hline Status & $\begin{array}{l}\text { Part-time/full- } \\
\text { time wage differ- } \\
\text { ential }(\beta)\end{array}$ & Observations \\
\hline $\begin{array}{l}\text { Not commuter (city of residence is the } \\
\text { same as city where the job is located) }\end{array}$ & $+0.048^{* * *}(0.0002)$ & $13,963,314$ \\
$\begin{array}{l}\text { Commuter (city of residence is not the } \\
\text { same as city where the job is located) }\end{array}$ & $+0.045^{* * *}(0.0001)$ & $19,125,107$ \\
\hline \hline
\end{tabular}

Source: INPS data; years: 2009-2015

All regressions include the same controls of Model 8, Table 1. All regressions are run on split samples. For all the rest, see the footnote of Table 1. 


\section{Appendices}

A. Identifying observations and selection issues

Table A.1: Observations used to identify part-time/full-time wage differential by estimation model. Female workers. Period: 2009-2015.

\begin{tabular}{l|lll|lll}
\hline \hline Estimation model & $\begin{array}{l}\text { All } \\
\text { workers }\end{array}$ & $\begin{array}{l}\text { Part- } \\
\text { time } \\
\text { work- } \\
\text { ers* }\end{array}$ & $\begin{array}{l}\text { Full- } \\
\text { time } \\
\text { work- } \\
\text { ers** }\end{array}$ & $\begin{array}{l}\text { All } \\
\text { workers, } \\
\text { \% lost }\end{array}$ & $\begin{array}{l}\text { Part- } \\
\text { time } \\
\text { workers, } \\
\text { \% lost }\end{array}$ & $\begin{array}{l}\text { Full- } \\
\text { time } \\
\text { workers, } \\
\text { \% lost }\end{array}$ \\
\hline $\begin{array}{l}\text { Pooled OLS } \\
\begin{array}{l}\text { Worker fixed effects (all } \\
\text { switches) }\end{array}\end{array}$ & $\begin{array}{l}33,088,421 \\
\text { Worker, firm, and match }\end{array}$ & $\begin{array}{l}13,966,248 \\
\text { fixed effects (switches } \\
\text { within the same firm) }\end{array}$ & $792,079,122,173$ & - & - & - \\
\hline \hline
\end{tabular}

Source: INPS data; years: 2009-2015

* In the case of worker fixed effects or worker, firm, and match fixed effects, this is the number of workers who switch from full-time to part-time work.

** In the case of worker fixed effects or worker, firm, and match fixed effects, this is the number of workers who switch from part-time to full-time work. 


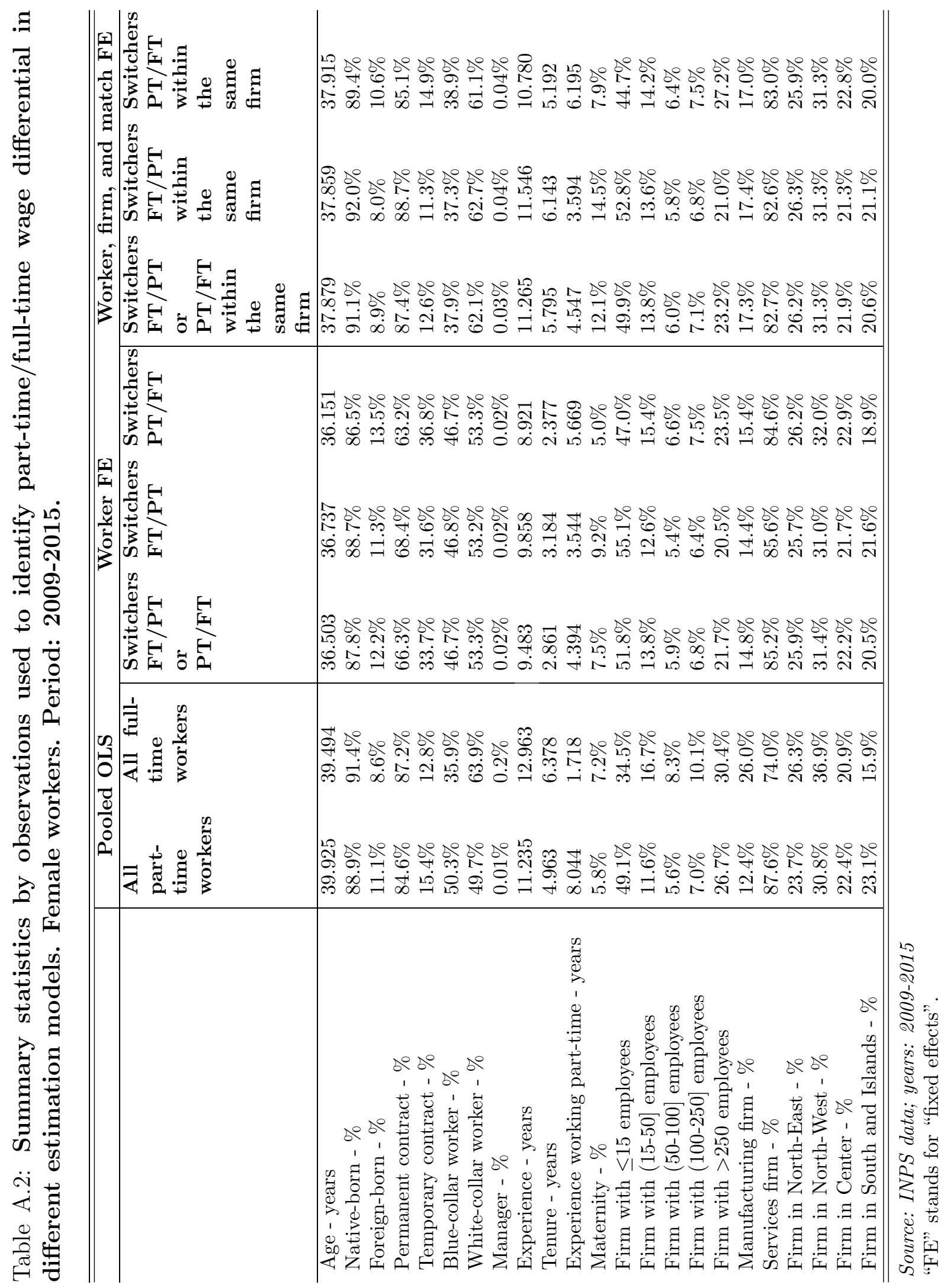




\section{Table A.3: Switching probability by AKM worker effects. Female workers. Period: 2009-2015}

\begin{tabular}{|c|c|}
\hline \multicolumn{2}{|c|}{ Dependent variable: switcher FT/PT or PT/FT within the same firm } \\
\hline AKM worker effects - 2nd decile & $-0.0019^{* * *}(0.0002)$ \\
\hline AKM worker effects - 3rd decile & $-0.0014^{* * *}(0.0002)$ \\
\hline AKM worker effects - 4th decile & $(0.0002)$ \\
\hline AKM worker effects - 5th decile & +0.0003 \\
\hline AKM worker effects - 6th decile & $+0.0007^{* * *}(0.0002)$ \\
\hline AKM worker effects - 7th decile & +0.0003 \\
\hline AKM worker effects - 8th decile & $-0.0012^{* * *}(0.0002)$ \\
\hline AKM worker effects - 9th decile & $-0.0040 * * *(0.0002)$ \\
\hline AKM worker effects - 10th decile & $-0.0069^{* * *}(0.0002)$ \\
\hline \multicolumn{2}{|r|}{ Observations: $26,268,852$} \\
\hline \multicolumn{2}{|c|}{ Dependent variable: switcher FT/PT within the same firm } \\
\hline AKM worker effects - 2nd decile & $-0.0018^{* * *}(0.0002)$ \\
\hline AKM worker effects - 3rd decile & $-0.0015^{* * *}(0.0002)$ \\
\hline AKM worker effects - 4 th decile & $-0.0009^{* * *}(0.0002)$ \\
\hline AKM worker effects - 5th decile & $-0.0003^{* *} \quad(0.0002)$ \\
\hline AKM worker effects - 6 th decile & +0.0000 \\
\hline AKM worker effects - 7 th decile & +0.0001 \\
\hline AKM worker effects - 8th decile & $-0.0004^{* *} \quad(0.0002)$ \\
\hline AKM worker effects - 9th decile & $-0.0017^{* * *}(0.0002)$ \\
\hline \multirow[t]{2}{*}{ AKM worker effects - 10th decile } & $-0.0039 * * *(0.0002)$ \\
\hline & Observations: $26,268,852$ \\
\hline
\end{tabular}

Source: INPS data; years: 2009-2015

All regressions include the same controls of Model 8, Table 1, except for worker and firm fixed effects, which are not included. Note that AKM worker effects are time-invariant. All regressions are run on split samples. AKM worker effects are derived from AKM regressions with two-way fixed effects computed over the period 2005-2009. For all the rest, see the footnote of Table 1 . 


\section{B. Male workers}

Table B.1: Evolution of estimated part-time/full-time wage differential and share of part-time workers. Male workers. Period: 1983-2015.

\begin{tabular}{llll}
\hline \hline Sub-period & $\begin{array}{l}\text { Part-time/full-time } \\
\text { wage differential } \\
(\beta)\end{array}$ & $\begin{array}{l}\text { Share of part-time } \\
\text { workers }\end{array}$ & Observations \\
\hline $1983-1987$ & $\begin{array}{l}+0.169^{* * *} \\
(0.0002) \\
+0.137^{* * *}\end{array}$ & $0.3 \%$ & $25,047,046$ \\
$1985-1989$ & $0.6 \%$ & $25,578,351$ \\
$1988-1993$ & $\begin{array}{l}(0.0006) \\
+0.105^{* * *}\end{array}$ & $1.0 \%$ & $32,904,218$ \\
$1992-1997$ & $\begin{array}{l}(0.0004) \\
+0.053^{* * *}\end{array}$ & $2.1 \%$ & $32,080,120$ \\
$1996-2001$ & $\begin{array}{l}(0.0003) \\
+0.039^{* * *}\end{array}$ & $3.2 \%$ & $34,433,755$ \\
$2000-2005$ & $\begin{array}{l}(0.0003) \\
+0.027^{* * *}\end{array}$ & $4.1 \%$ & $38,267,854$ \\
$2004-2009$ & $(0.0002)$ & $6.6 \%$ & $40,115,889$ \\
$2009-2015$ & $-0.001^{* * *}$ & $11.0 \%$ & $45,787,468$ \\
& $(0.0002)$ & & \\
\hline \hline
\end{tabular}

Source: INPS data; years: 1983-2015

All regressions include the same controls of Model 8, Table 1. "n.s." denotes non-significance at the $10 \%$ level. For all the rest, see the footnote of Table 1. 


\section{References}

Aaronson, D., French, E., 2004. The Effect of Part-Time Work on Wages: Evidence from the Social Security Rules. Journal of Labor Economics 22 (2), 329-352.

Abowd, J. M., Kramarz, F., Margolis, D. N., 1999. High Wage Workers and High Wage Firms. Econometrica 67 (2), 251-333.

Bardasi, E., Gornick, J. C., 2008. Working for Less? Women's Part-Time Wage Penalties across Countries. Feminist Economics 14 (1), 37-72.

Barzel, Y., 1973. The Determination of Daily Hours and Wages. The Quarterly Journal of Economics 87 (2), 220-238.

Booth, A., Wood, M., 2008. Back-to-Front Down Under? Part-Time/Full-Time Wage Differentials in Australia. Industrial Relations. A Journal of Economy and Society 47 (1), $114-135$.

Card, D., Devicienti, F., Maida, A., 2014. Rent-Sharing, Holdup, and Wages: Evidence from Matched Panel Data. The Review of Economic Studies 81 (1), 84-111.

Connolly, S., Gregory, M., 2009. The Part-Time Pay Penalty: Earnings Trajectories of British Women. Oxford Economic Papers 61 (Suppl. 1), i76-i97.

Day, I., Rodgers, J., 2015. The Premium for Part-time Work in Australia. Australian Journal of Labour Economics 18 (3), 281-305.

Devicienti, F., Fanfani, B., Maida, A., 2019. Collective Bargaining and the Evolution of Wage Inequality in Italy. British Journal of Industrial Relations 57 (2), 377-407.

Devicienti, F., Grinza, E., Vannoni, D., 2018. The Impact of Part-Time Work on Firm Productivity: Evidence from Italy. Industrial and Corporate Change 27 (2), 321-347.

Elsayed, A., de Grip, A., Fouarge, D., 2017. Computer Use, Job Tasks and the Part-Time Pay Penalty. British Journal of Industrial Relations 55 (1), 58-82.

Ermisch, J. F., Wright, R. E., 1993. Wage Offers and Full-Time and Part-Time Employment by British Women. The Journal of Human Resources 28 (1), 111-133.

Eurofound, ILO, 2019. Working Conditions in a Global Perspective. Tech. rep., European Foundation for the Improvement of Living and Working Conditions and International Labour Organization, Dublin, IRL and Geneva, CH. 
Eurostat, 2009. Reconciliation between Work, Private and Family Life in the European Union. Tech. rep., European Statistical Office, Kirchberg, LU.

Fernández-Kranz, D., Paul, M., Rodríguez-Planas, N., 2015. Part-Time Work, Fixed-Term Contracts, and the Returns to Experience. Oxford Bullettin of Economics and Statistics 77 (4), 512-541.

Fernández-Kranz, D., Rodríguez-Planas, N., 2011. The Part-Time Pay Penalty in a Segmented Labor Market. Labour Economics 18 (5), 591-606.

Gallego Granados, P., 2019. The Part-Time Wage Gap across the Wage Distribution, dIW Discussion Papers, No. 1791.

Gasparini, G., Parent-Thirion, A., Latta, M., de Nanteuil, M., 2012. Full-Time or Part-Time Work: Realities and Options. Tech. rep., European Foundation for the Improvement of Living and Working Conditions, Dublin, IRL.

Hardoy, I., Schøne, P., 2006. The Part-Time Wage Gap in Norway: How Large is It Really? British Journal of Industrial Relations 44 (2), 263-282.

Hirsh, B. T., 2005. Why Do Part-Time Workers Earn Less? The Role of Worker and Job Skills. Industrial \& Labor Relations Review 58 (4), 525-551.

Jepsen, M., O’Dorchai, S., Plasman, R., Rycx, F., 2005. The Wage Penalty Induced by Part-Time Work: The Case of Belgium. Brussels Economic Review 48 (1/2), 73-74.

Manning, A., Petrongolo, B., 2009. The Part-Time Pay Penalty for Women in Britain. The Economic Journal 118 (526), F28-F51.

Matteazzi, E., Pailé, A., Solaz, A., 2014. Part-Time Wage Penalties for Women in Prime Age: A Matter of Selection or Segregation? Evidence from Four European Countries. Industrial \& Labor Relations Review 67 (3), 955-985.

Matteazzi, E., Pailé, A., Solaz, A., 2018. Part-Time Employment, the Gender Wage Gap and the Role of Wage-Setting Institutions: Evidence from 11 European Countries. European Journal of Industrial Relations 24 (3), 22-241.

Moffitt, R., 1984. The Estimation of a Joint Wage-Hours Labor Supply Model. Journal of Labor Economics 2 (4), 550-566.

Montgomery, M. R., 1988. On the Determinants of Employer Demand for Part-Time Workers. The Review of Economics and Statistics 70 (1), 112-117. 
Mulalic, I., Van Ommeren, J. N., Pilegaard, N., 2014. Wages and Commuting: Quasi-Natural Experiments' Evidence from Firms that Relocate. The Economic Journal 124 (579), 10861105.

Mumford, K., Smith, P. N., 2009. What Determines the Part-Time and Gender Earnings Gaps in Britain: Evidence from the Workplace. Oxford Economic Papers 61 (Supplement: Women and Wages), i56-i75.

Nightingale, M., 2019. Looking beyond Average Earnings: Why Are Male and Female PartTime Employees in the UK More Likely to Be Low Paid Than Their Full-Time Counterparts? Work, Employment and Society 33 (1), 131-148.

O'Dorchai, S., Plasman, R., Rycx, F., 2007. The Part-Time Wage Penalty in European Countries: How Large Is It for Men? International Journal of Manpower 28 (7), 571-603.

OECD, 2017. OECD Guidelines on Measuring the Quality of the Working Environment. Tech. rep., Organisation for Economic Co-operation and Development, Paris, FR.

Oi, W. Y., 1962. Labor as a Quasi-Fixed Factor. Journal of Political Economy 70 (6), 538555.

Owen, J. D., 1978. Working Hours: An Economic Analysis. Lexington Books, Lexington, MA.

Pacelli, L., Pasqua, S., Villosio, C., 2013. Labor Market Penalties for Mothers in Italy. Journal of Labor Research 34 (4), 408-432.

Paul, M., 2016. Is There a Causal Effect of Working Part-Time on Current and Future Wages? The Scandinavian Journal of Economics 118 (3), 494-523.

Pissarides, C., Garibaldi, P., Olivetti, C., Petrongolo, B., Wasmer, E., 2005. Women in the Labour Force: How Well is Europe Doing?, Sciences Po Publications, Paris, FR.

Simon, H., Sanroma, E., Ramos, R., 2017. Full- and Part-Time Wage Differences in Spain: An Analysis along the Wage Distribution. International Journal of Manpower 38 (3), 449469.

Tummers, M. P., Woittiez, I., 1991. A Simultaneous Wage and Labor Supply Model with Hours Restrictions. The Journal of Human Resources 26 (3), 393-423.

Wolf, E., 2002. Lower Wage Rates for Fewer Hours? A Simultaneous Wage-Hours Model for Germany. Labour Economics 9 (5), 643-663. 